\title{
Radial Growth Responses of Four Deciduous Species to Climate Variables in Central Ontario, Canada
}

\author{
Martin Kwiaton, Jian R. Wang* \\ Faculty of Natural Resources Management, Lakehead University, Thunder Bay, Canada \\ Email: ${ }^{\text {jian.wang@lakeheadu.ca }}$
}

Received 25 July 2015; accepted 1 September 2015; published 4 September 2015

Copyright (C) 2015 by authors and Scientific Research Publishing Inc.

This work is licensed under the Creative Commons Attribution International License (CC BY). http://creativecommons.org/licenses/by/4.0/

c) (i) Open Access

\section{Abstract}

To address the central question of how climate change influences tree growth within the context of climate will become warmer and drier in central Ontario, we used dendroclimatological analysis to understand the radial growth responses of four co-occurring hardwood species: sugar maple (Acer saccharum Marsh.), yellow birch (Betula alleghaniensis Britton), American beech (Fagus grandifolia Ehrh.), and red oak (Quercus rubra L.) to climatic variables in central Ontario, Canada. Ring width chronologies were developed for the target species within three regions (Algonquin Park, Haliburton, and North Bay) of the study area. Seven of the eleven chronologies exceeded the 0.85 expressed population signal (EPS) and were used for further analysis. Mean sensitivity and standard deviation values of the Ontario chronologies indicated lower sensitivity to climate fluctuations than in southern North America. Positive correlations with precipitation variables from the current and prior growing season supported previous studies in sugar maple, while a positive response to growing degree days suggested the importance of warmer temperatures and a longer growing season at the northern limit of the distribution range of sugar maple. Yellow birch ring width was correlated with precipitation from the previous growing season and from the end of the current growing season also suggesting that mature trees with deep root systems might utilize moisture from deep soil. Radial growth of American beech positively correlated to precipitation of the previous season, suggesting that the amount of moisture reserves stored in the previous year might affect growth in the following year. Drought stress at the start of the growing season for red oak had negative correlations with precipitation in August indicating possible cessation of cambial activity. This decline in growth process would also affect ring width of red oak the following year as expressed by negative correlations with mean annual temperature from the previous year. Abnormally, warm seasonal temperatures may be indicative of drought stress in red oak.

\footnotetext{
${ }^{*}$ Corresponding author.
}

How to cite this paper: Kwiaton, M. and Wang, J.R. (2015) Radial Growth Responses of Four Deciduous Species to Climate Variables in Central Ontario, Canada. American Journal of Plant Sciences, 6, 2234-2248. 


\section{Keywords}

\section{Acer saccharum, Betula alleghaniensis, Quercus rubra, Fagus grandifolia, Tree Ring Width, Climate Variables}

\section{Introduction}

It has been widely documented that tree rings are an efficient tool in reconstructing past climate conditions and creating tree ring chronologies [1] [2]. These tree ring chronologies can be used to evaluate impacts of climatic changes on forest productivity, vegetation dynamics, plant diversity and species richness [3]-[6]. Between 1906 and 2005 global average surface temperatures have increased by $0.74^{\circ} \mathrm{C}$, and projections of future climate change based on different emission scenarios of greenhouse gases indicate further increases of $1.1^{\circ} \mathrm{C}-6.4^{\circ} \mathrm{C}$ by the end of the $21^{\text {st }}$ century in relation to $1980-1999$ [7]. Dendrochronology, also known as tree-ring dating, is the analysis of tree ring growth patterns for scientific dating of events and variations in the environment [8]. Traditionally, in dendrochronology, conifers have received much more attention than hardwoods [9]. Currently no dendrochronology studies relating tree ring width to climatic variables have been conducted in Ontario. It is important to determine how climatic variables influence radial growth in trees to help project future growth responses in the context of climate change [10]-[12].

Sugar maple (Acer saccharum Marsh.), yellow birch (Betula alleghaniensis Britton), American beech (Fagus grandifolia Ehrh.), and red oak (Quercus rubra L.) accounted for 97.1\% of the total hardwood harvest volume in the Great Lakes-St. Lawrence Forest Region of Central Ontario in 2005-06. Sugar maple alone accounted for $78.5 \%$ and each species has increased total harvest volumes by $41 \%, 64 \%, 77 \%$, and 55\% respectively since 2001-02 [13]. These species across the landscape of central Ontario are vital to biodiversity and maintaining social, ecological, and economical balance in future forest management planning. Previous studies on the influence of climate on tree rings were found for red oak [9], sugar maple [14] in southwestern Quebec and Michigan [15], and American beech in southwestern Quebec [16] and yellow birch in Massachusetts [17]. The geographical proximity of these studies will allow for an exceptional comparison with the results from this study. Sugar maple requires a cool moist climate for optimal growth. In the northeastern region where substantial commercial volumes of sugar maple are located, it receives roughly $1270 \mathrm{~mm}$ in annual precipitation [18]. Annual precipitation ranges from $510 \mathrm{~mm}$ to $2030 \mathrm{~mm}$ from the western limit of its range to the southern Appalachians. Growing season precipitation ranges from $380 \mathrm{~mm}$ (western areas) to $1020 \mathrm{~mm}$ (in the east) and ranges from 80 to 260 days. Spring thaw, the last killing frost, usually occurs anywhere from March 20 to June 15 [19]. Radial and height growth begins at the same time as buds leaf out [18]. Height growth is completed within 15 weeks, with $85 \%$ of the growth complete within 5 weeks. Radial growth is completed within 14 to 17 weeks depending on the area and $80 \%$ of the cambial growth is complete in 8 weeks [18].

Yellow birch is also a species adapted to growing in cool areas with abundant soil moisture. The northern limit of its range in Canada coincides with a $2^{\circ} \mathrm{C}$ mean annual temperature isotherm. Annual precipitation ranges from $640 \mathrm{~mm}$ to $1270 \mathrm{~mm}$, increasing from its western to eastern limit. With similar moisture requirements as sugar maple, yellow birch grows at wetter microsites. Located on lower slopes and in depressions yellow birch requires less annual precipitation due to its location on less-drained soil than sugar maple that is more often found on upland and level sites. Therefore, yellow birch has a higher site index than sugar maple. The growing season ranges from 60 to 150 days, averaging around 120 days [20].

Water availability is vital in growth processes in American beech. As a mesophytic species, beech uses twice as much as water annually for transpiration and growth processes in comparison to some drought resistant oaks [21]. Annual precipitation within its range varies from $760 \mathrm{~mm}$ to $1270 \mathrm{~mm}$ whereof only $250 \mathrm{~mm}$ to $460 \mathrm{~mm}$ during the growing season [22]. The mean annual temperature isotherm for American beech at the northern limit of its range is $4^{\circ} \mathrm{C}$. Higher than average summer temperatures may be unfavorable for growth processes in beech as the length of the growing series ranges widely from 100 to 280 days [21]. Radial growth has been noted to continue from 80 to 89 days in the Georgia Piedmont and roughly 60 days in Indiana [22]. The radial growth period ends in the middle of July under normal conditions; however drought may cause growth to cease a month earlier in mid-June. Radial growth is influenced by available soil moisture and generally does not begin until the 
leaves are fully expanded [21].

In the northern limit of its range, red oak grows in cool moist climates in deep well drained soils [23]. Annual precipitation ranges from $760 \mathrm{~mm}$ in the northwest to $2030 \mathrm{~mm}$ in the southern Appalachians. Mean annual temperature isotherm for red oak at its northern limit is just below $4^{\circ} \mathrm{C}$. The growing season averages 100 days in the north and 220 days in the southern limit of its range [24] (Sander 1990). Optimal growth is dependent on soil depth, texture, and microsite positioning. Lower and middle slopes are preferred, as well as well drained valley floors [24]. In the cambium, once leaf expansion is complete, earlywood formation from the initiation of vessel elements to complete maturation lasts roughly 10 weeks [25]. Thus, earlywood formation is strongly dependent on carbohydrate storage from the previous year [26].

In-depth, comparison of the same tree species under comparable ecological conditions from the same stands is rare but urgently needed in the discussion of species-specific responses to climate change and in the anticipation of trends in regional forest dynamics. Furthermore, the temporal stability of climatic influences on tree growth in central Ontario temperate forests has not been studied sufficiently, despite the fact that such knowledge is essential to assess the effects of climate change upon forest productivity. The objectives of this study were to 1) develop tree-ring width chronologies for the four hardwood species in central Ontario, and 2) analyze these chronologies in relation to climatic variables to examine any differences among these co-occurring species. If different species were growing on the same site, then the differences in response to climatic variables should represent the species adaptation to the specific climate variables. All four species are at or near their northern limit and as such the species are expected to be more sensitivity to climatic change. We hypothesized that drought stresses will have the largest effect on radial growth rate of all four species, as none of them has been considered to be drought tolerant [27].

\section{Methods}

\subsection{Study Area}

The study area ranged from North Bay in the north, to south of Sudbury in the west, Haliburton in the south, and the southeast section of Algonquin Park to the east. The study area was divided into three sections: Haliburton Forest and Wildlife Preserve (Haliburton); the southern half of Algonquin Provincial Park (Algonquin); and the portion of crown forest extending east from Sudbury to North Bay (North Bay). The four hardwood species were sugar maple, American beech, yellow birch, and red oak. Each section contained the four target species except for North Bay, which lies north of American Beech's distribution range. The three sections of the Great Lakes-St. Lawrence Forest Region were chosen to best represent tree-growth/climate relationship under slightly different moisture conditions from east to west and temperature gradient from south to north.

\subsection{Field Sampling}

Fifty stands were randomly sampled from candidate forests that were identified using Forest Resources Inventory (FRI) maps from government, commercial and private forests, Ontario Ministry of Natural Resources (OMNR) Permanent Sample Plot (PSP) databases and local knowledge [28]. One $100 \mathrm{~m}^{2}$ study plot per stand was located within the selected stand relatively uniform in overall stand characteristics, soils and understory vegetation. Trees greater than $4 \mathrm{~cm}$ in diameter at breast height (dbh) were measured for total height, dbh, and age. For stem analysis, three healthy, undamaged and vigorous trees of each target species were felled in each stand. The sampled trees were free growing dominants with no evidence of suppression. All trees sampled were greater than 50 years old at breast height. Tree discs were cut at breast height $(1.3 \mathrm{~m})$. Tree discs were sanded in the laboratory using a belt sander and scanned at 800 or 1600 dpi using an Epson scanner. Tree ring width was measured using Win Dendro software [29] from 2 radii.

\subsection{Tree-Ring Analysis and Chronology Development}

In total, 182 trees were used for the analysis (Table 1). Tree-ring standardization, the removal of biologically induced age-trend [1], was performed using the program ARSTAN [30]. Using ARSTAN [30] [31], each ring-width series was detrended producing ring width indices (RWI). These chronological indices represent a robust estimation of exogenous climate and endogenous growth dynamics in tree ring series and are considered to contain a strong climate signal [30]. A chronology was developed for each species at each site resulting in 11 
Table 1. Number of sampled plots and mean breast height age (BHA) by tree species and regions within the three study areas.

\begin{tabular}{|c|c|c|c|c|c|c|}
\hline \multirow{2}{*}{\multicolumn{2}{|c|}{ Sample Plots (Trees) }} & \multicolumn{4}{|c|}{ Species } & \multirow[b]{2}{*}{ Total } \\
\hline & & American Beech & Sugar Maple & Red Oak & Yellow Birch & \\
\hline \multirow{3}{*}{ Region } & North Bay & NA & $7(20)$ & $1(3)$ & $2(6)$ & $10^{*}(29)$ \\
\hline & Haliburton & $10(26)$ & $12(28)$ & $4(12)$ & $6(15)$ & $19^{*}(81)$ \\
\hline & Algonquin & $8(21)$ & $13(36)$ & $4(12)$ & $1(3)$ & $21^{*}(72)$ \\
\hline \multirow[t]{3}{*}{ Totals } & & $18(47)$ & $32(84)$ & $9(27)$ & $9(24)$ & $50^{*}(182)$ \\
\hline & BHA & & & & & \\
\hline & North Bay & NA & 80.8 & 80.3 & 124.8 & 89.9 \\
\hline \multirow[t]{2}{*}{ Region } & Haliburton & 109.7 & 103 & 79.6 & 72.1 & 96 \\
\hline & Algonquin & 126.8 & 102.9 & 110.5 & 52.7 & 109.1 \\
\hline \multicolumn{2}{|c|}{ Total Mean } & 117.3 & 97.7 & 93.4 & 82.9 & 100.2 \\
\hline
\end{tabular}

*Note: Some plots had more than one species occurring in them, hence this number is less than the sum of individual plots by species; NA: No data available because there was no American beech distribution in North Bay area.

chronologies. Various statistical parameters were calculated to compare the standardized tree-ring chronologies. We also calculated the expressed populations signal (EPS), which is expected to measure chronology reliability, using a moving window approach [32] along each chronology. Mean sensitivity (MS), standard deviation (SD) and autocorrelation (AC) were also calculated for each chronology. Autocorrelation assesses the similarity between a given time series (tree ring chronology) and a lagged version of itself over successive time intervals. It is identical to calculating the correlation between two different time series, except that the same time series is used twice [33].

\subsection{Tree Ring Width and Climate Variable Correlations}

Climate data were obtained from the Environment Canada Weather Office Historic Climate Data website [34]. The data were collected from local weather stations within close proximity to the sample sites. Climate data were dating back to the early 1890's for the Haliburton sample area; however the data for the analysis were not collected until 1940, which was the earliest records that were found in the North Bay region of the study area. Radial growth of trees from lower elevations generally reflects precipitation changes, whereas radial growth of trees from higher elevations generally mirrors temperature variations [35]. Since the sampled sites were at lower elevations a larger emphasis was placed on precipitation in this study. Two groups of regional climate variables were used to evaluate climate-radial growth relationships: previous year precipitation in May (PrMayP), June (PrJuneP), July (PrJulyP), August (PrAugustP), September (PrSeptP), total (PrTotalP), June thru August (PrJJAP), May thru August (PrMJJAP), and mean precipitation in May (MayP), June (JuneP), July (JulyP), August (AugustP), September (SeptP), mean annual temperature (MAT), mean annual temperature for the previous year (PrMAT), growing degree days above 0, 5, and 10 degrees Celsius (GDD0, GDD5, GDD10, respectively). Pearson Product-Moment Correlation analysis was used as each residual chronology was tested against these climatic variables. A centralized location was also selected within the study area (Huntsville, ON) to gather climate information (Figure 1) and run analysis against chronologies that were developed for each tree species across the entire study area. Additional information on the climate at each of the three sites and the centralized location is shown in Table 2. Significance was set at $\alpha<0.05$ for all analyses.

\section{Results}

\subsection{Cross-Dating and Chronology Descriptive Statistics}

A total of 182 trees was successfully cross-dated, measured, and averaged by species and by site to reduce noise: 84 sugar maple, 24 yellow birch, 27 red oak and 47 American beech. Standard and residual tree-ring chronologies were successfully developed for the four species from the three sample areas (Figures 2-5). There was no natural distribution of American beech in the North Bay sample area. We also pooled the ring width data from the three sample areas by species and developed an additional tree-ring chronology across the entire central On- 
Table 2. Additional climate information collected from four weather stations: North Bay, Algonquin Park, Haliuburton and Huntsville; to be used in the ring width analysis.

\begin{tabular}{ccccc}
\hline & North Bay & Haliburton & Algonquin Park & Huntsville \\
\hline Daily Mean Temp $\left({ }^{\circ} \mathrm{C}\right)$ & 3.8 & 4.9 & 4 & 5.4 \\
Mean Daily Range $\left({ }^{\circ} \mathrm{C}\right)$ & 18.6 to -13.0 & 18.9 to -10.9 & 18.2 to -12.3 & 19.4 to -10.2 \\
July Temp. Range $\left({ }^{\circ} \mathrm{C}\right)$ & 23.8 to 13.3 & 24.9 to 12.9 & 25.5 to 10.9 & 25 to 13.8 \\
Mean Precip. $(\mathrm{mm})$ & 1007.7 & 1008.8 & 843.2 & 1031.9 \\
Rainfall $(\mathrm{mm})$ & 774.6 & 746.7 & 654.6 & 746.2 \\
Snowfall $(\mathrm{cm})$ & 273.4 & 262.2 & 188.7 & 285.6 \\
\hline
\end{tabular}

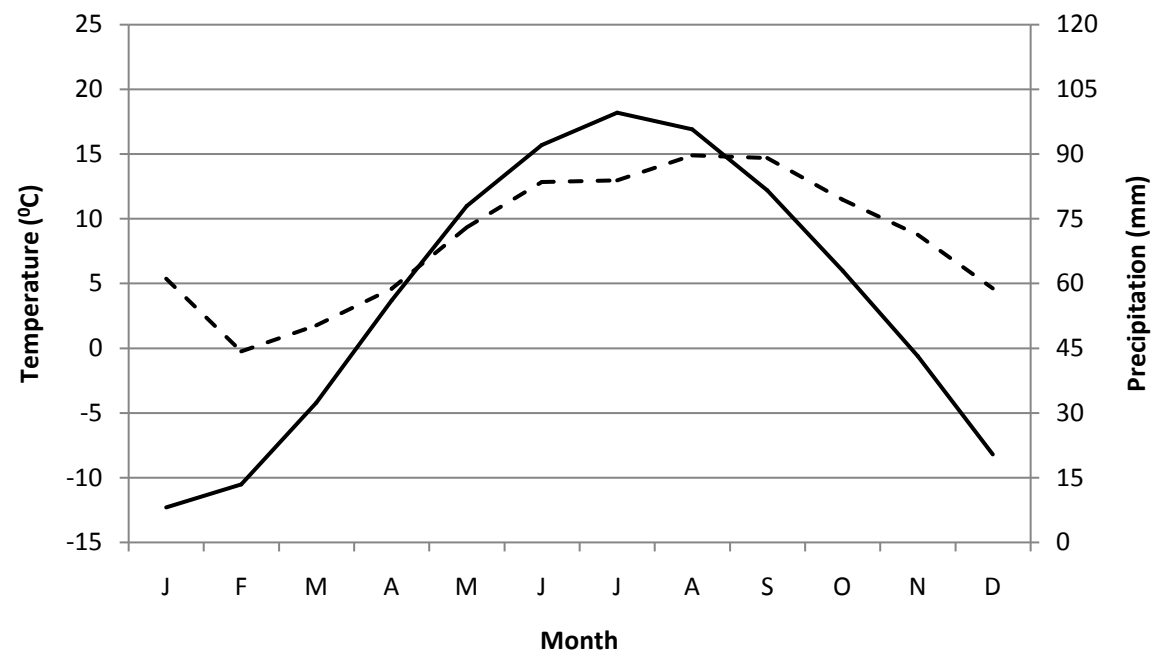

Figure 1. Mean monthly temperature (solid) and precipitation (dashed) for the centre of our study area in Huntsville, ON.
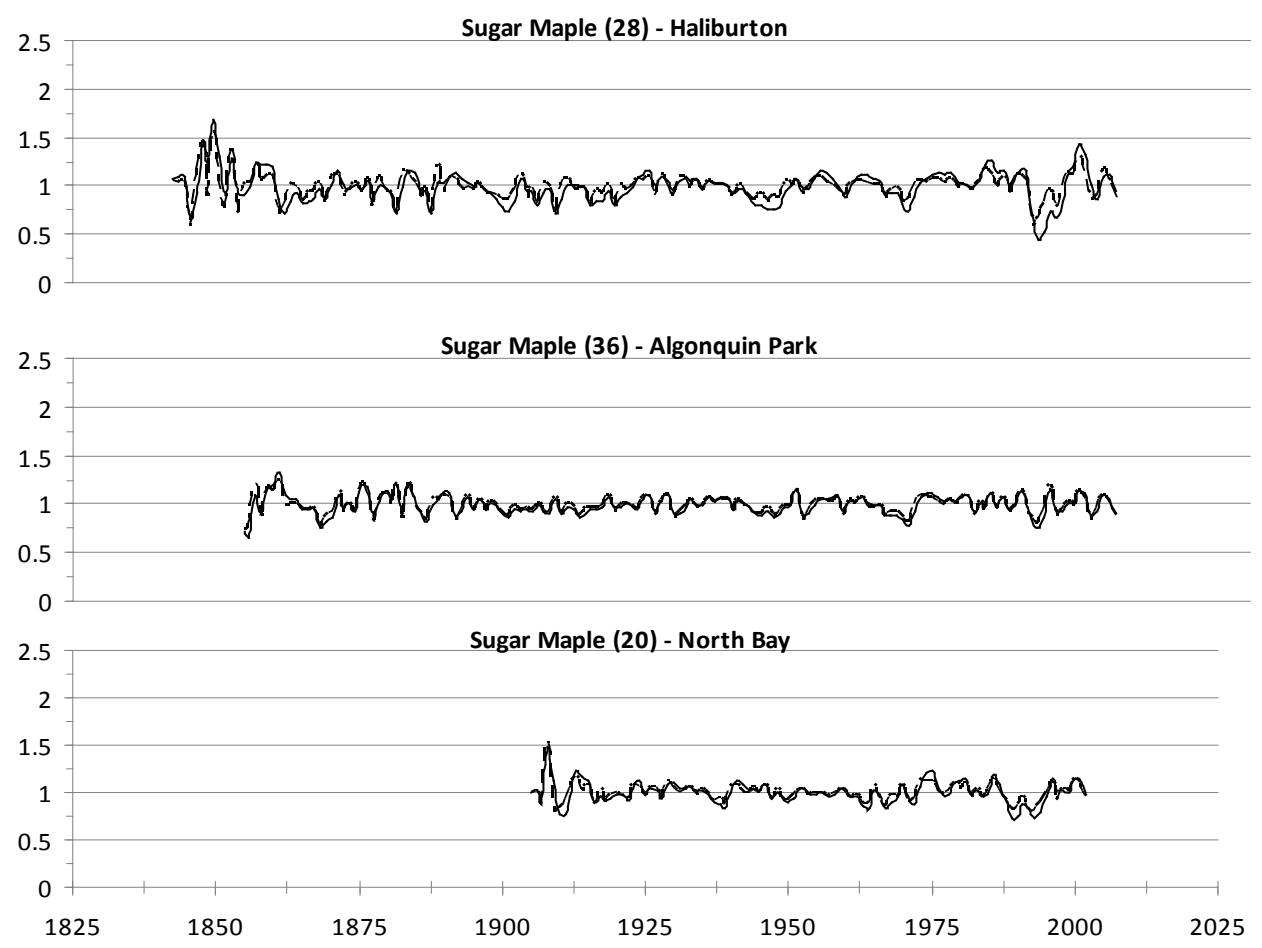

Figure 2. Ring width index standard (solid) and residual (dashed) chronologies developed for sugar maple in Haliburton, Algonquin Park, and North Bay using ARSTAN. Number of sampled trees per chronology is in parentheses. 
M. Kwiaton, J. R. Wang
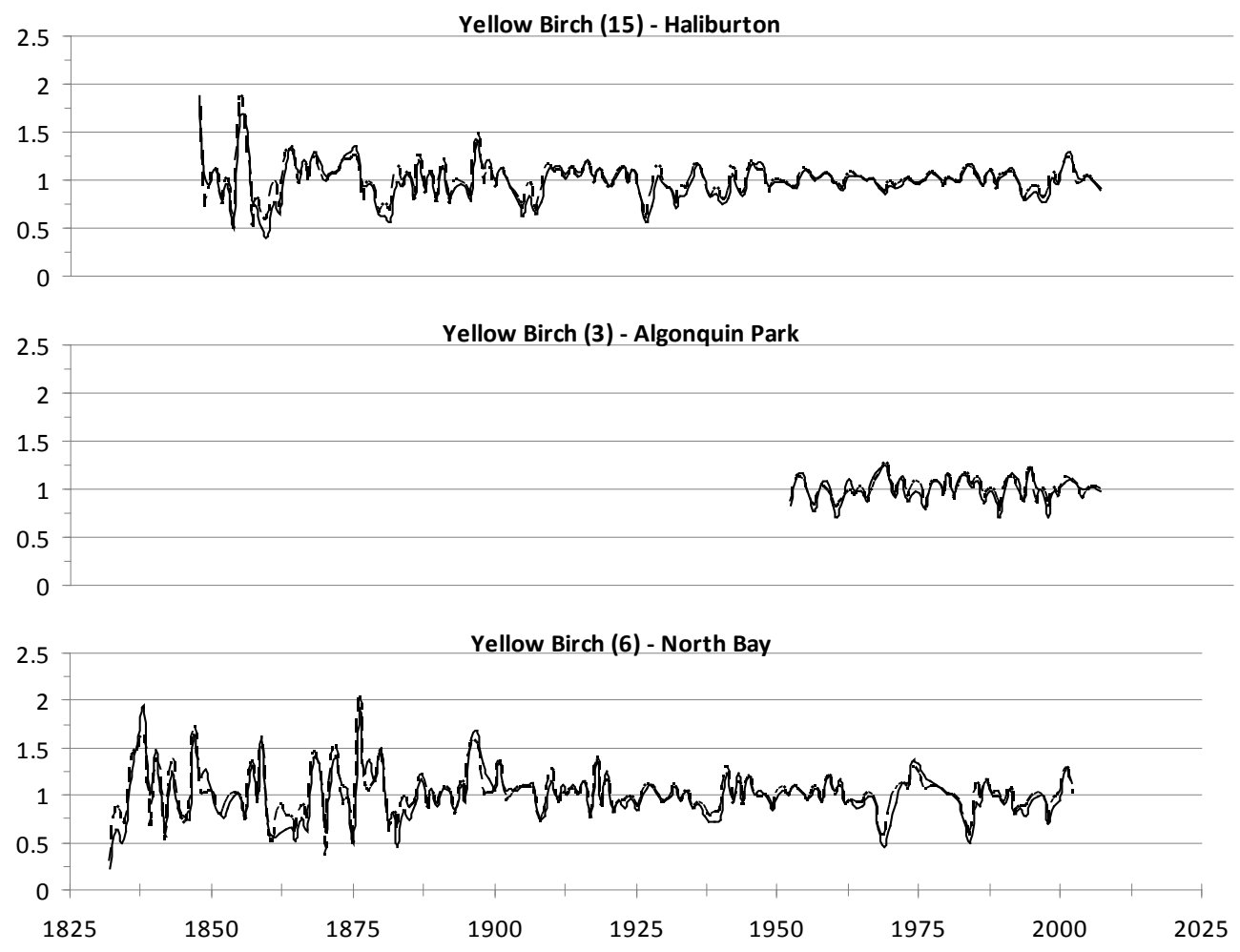

Figure 3. Standard (solid) and residual (dashed) chronologies developed for yellow birch in Halliburton, Algonquin Park, and North Bay using ARSTAN. Number of sampled trees per chronology is in parentheses.
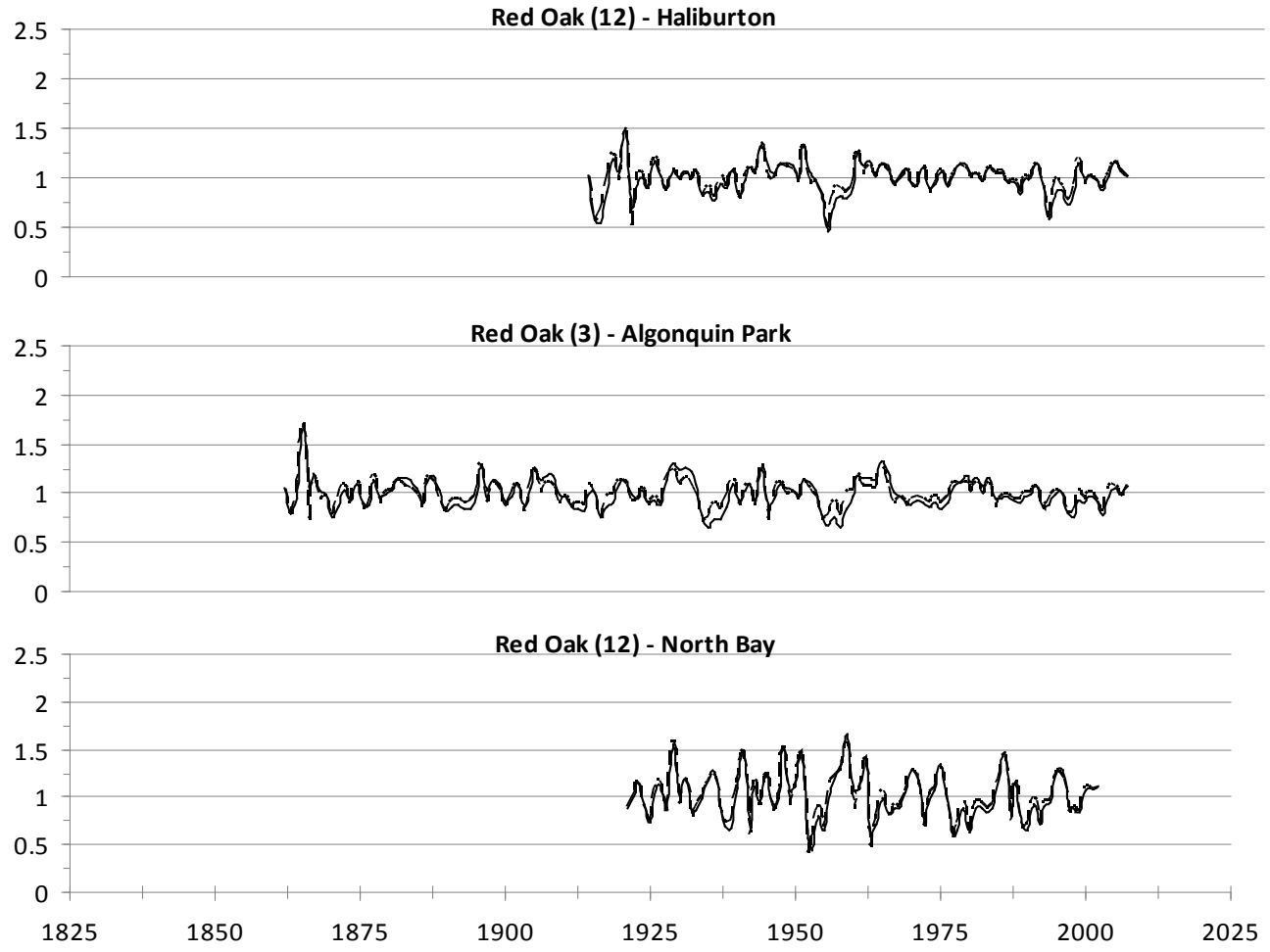

Figure 4. Standard (solid) and residual (dashed) chronologies developed for red oak in Haliburton, Algonquin Park, and North Bay using ARSTAN. Number of sampled trees per chronology is in parentheses.

2239 

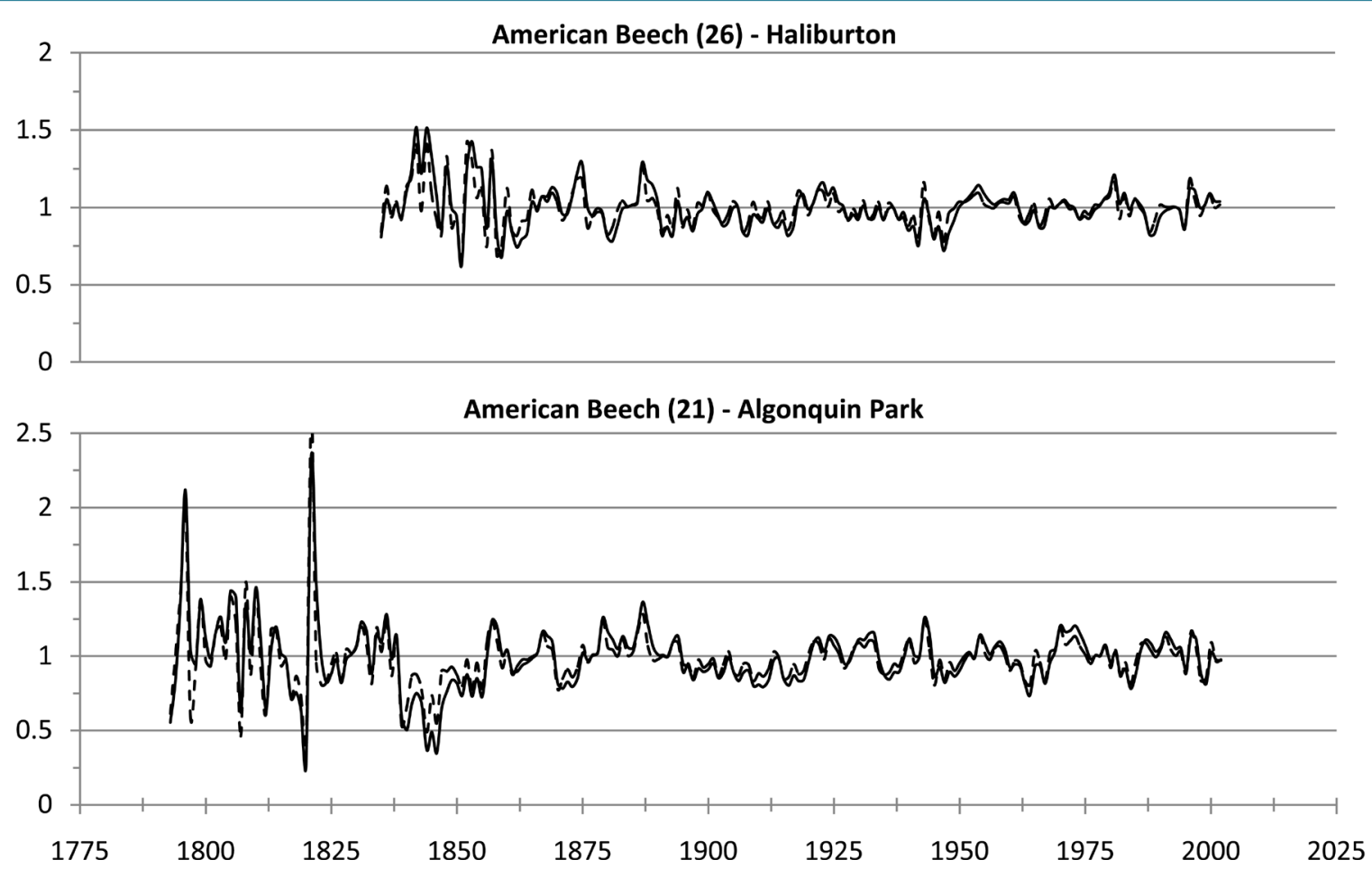

Figure 5. Ring width index standard (solid) and residual (dashed) chronologies developed for American beech in Haliburton and Algonquin Park using ARSTAN. Number of sampled trees per chronology is in parentheses.

tario region (Figure 6). Most tree-ring series showed an age-related exponential decrease in ring width. The resulting eleven chronologies ranged from 54 (yellow birch in North Bay) to 210 (American beech in Algonquin) years in range. The mean sensitivity ranged from 0.087 for sugar maple in North Bay to 0.248 for red oak in North Bay. The standard deviation was highest for the yellow birch chronology in North Bay (0.264) and lowest for the sugar maple chronology in Algonquin Park (0.103) (Table 3). The expressed population signal (EPS) is as high as 0.968 for the sugar maple chronology in Algonquin Park, however it is very low, 0.595, in chronologies with low number of samples such as the yellow birch chronology in North Bay that only contains five sample trees. Sugar maple chronologies in each of the three sample areas produced the highest EPS values when compared to other target species within each area; 0.968, 0.950, and 0.929 for Algonquin Park, Haliburton, and North Bay respectively.

First order autocorrelations of standard chronologies of ring width revealed stronger correlations in Haliburton for sugar maple (0.598) and American beech (0.507) than those for yellow birch (0.378) and red oak (0.362). In North Bay the sugar maple chronology had the strongest autocorrelation (0.457), followed by the yellow birch (0.308), and red oak (0.229) chronologies. In Algonquin Park the red oak chronology had the strongest autocorrelation (0.483) in first order autocorrelations of ring widths. Yellow birch revealed the lowest autocorrelation out of all the chronologies (0.189), with American beech (0.391) and sugar maple (0.350) falling in the middle (Table 3).

\subsection{Tree Ring Width Responses to Climate Variables}

Residual chronologies of ring widths for American beech responded positively to total precipitation from the previous year (PrTotalP), summer precipitation from the previous year (PrJJAP), and spring/summer precipitation from the previous year (PrMJJAP) in Haliburton (Figure 7(a)). Precipitation from the previous June (PrJuneP) showed a significant positive relationship in Haliburton and Algonquin Park. No other climatic variables showed significant correlations in the Algonquin Park. Negative correlations were found between ring width and May precipitation (MayP) in Haliburton, and between ring width and August precipitation from the previous year (PrAugustP) and mean annual temperature (MAT) in Algonquin Park. However, none of these negative correlations were significant at the $p<0.05$ level. 

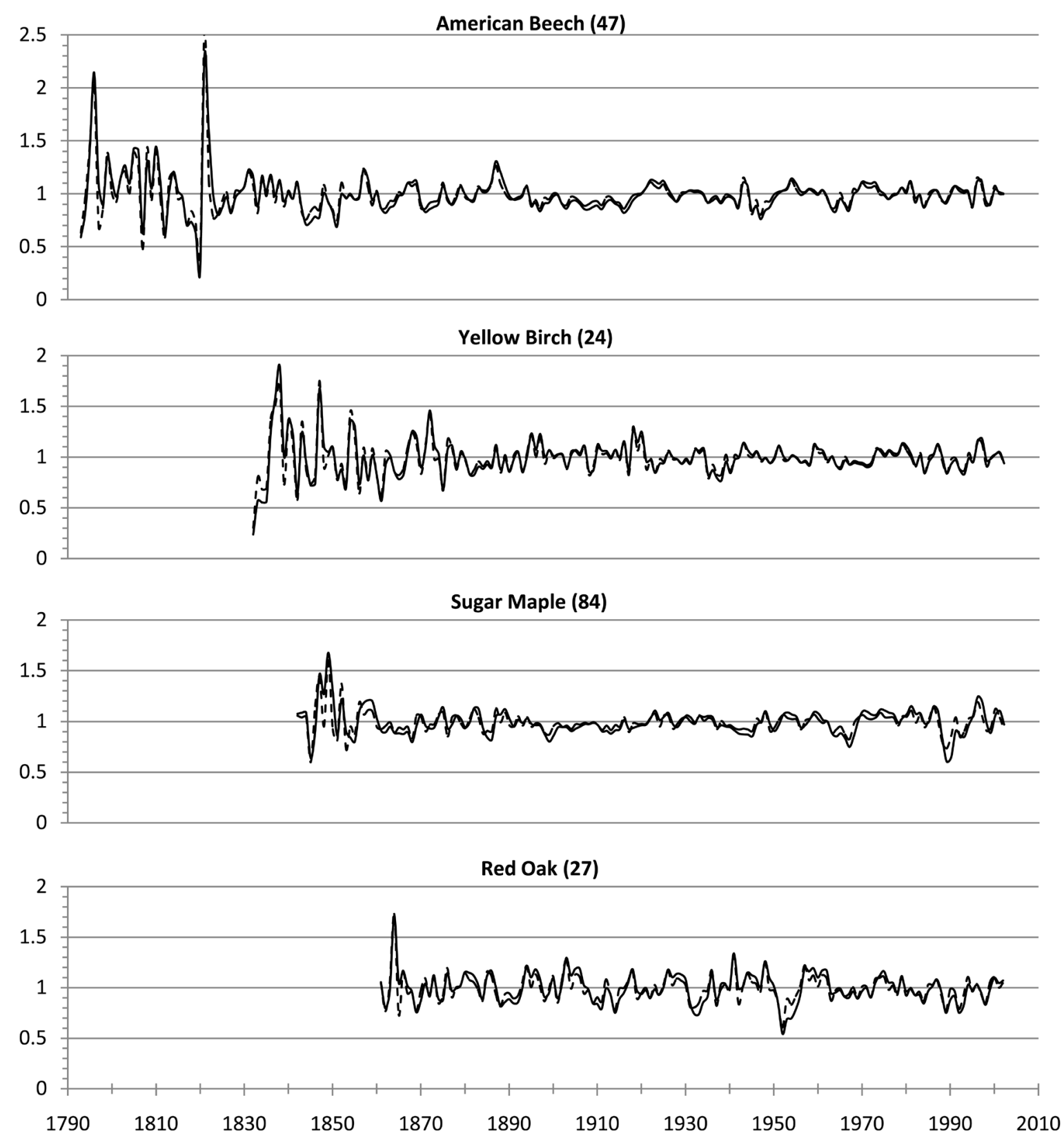

Figure 6. Standard (solid) and residual (dashed) chronologies developed for American beech, yellow birch, sugar maple, and red oak in Huntsville. Number of sampled trees per chronology is in parentheses.

Sugar maple residual chronologies had the most positive responses to climatic variables in comparison to all other three species that were studied. Strong correlation of ring width to PrTotalP, PrJJAP, PrMJJAP, PrJuneP, PrJulyP, and PrAugustP were found in the Haliburton study area (Figure 7(b)). In Algonquin Park similar correlations were found between ring width and PrJJAP, PrMJJAP, PrJuneP, and PrJulyP. In addition a significant correlation was found between mean July precipitation (JulyP) and ring width chronology for sugar maple. Significant relationships were present between PrTotalP, PrJJAP, PrMJJAP, PrJuneP, PrJulyP, JulyP, and the ring width chronology developed for the North Bay study area. However, this was the only chronology that displayed strong responses to growing degree days greater than or equal to $5^{\circ} \mathrm{C}$ (GDD5) and growing degree days greater than or equal to $10^{\circ} \mathrm{C}$ (GDD10). Sugar maple from Algonquin Park showed negative correlations with PrMayP, PrAugustP, MayP, and SeptP, and all sites showed some negative correlation with the mean annual temperature for the previous year (PrMAT), however none of the responses were significant at the $p<0.05$ level. 
Table 3. Chronology statistics from red oak, American beech, sugar maple, and yellow birch chronology development in Haliburton, North Bay, and Algonquin Park.

\begin{tabular}{|c|c|c|c|c|c|c|}
\hline Haliburton & Number of Trees & Length (yrs) & MS & STDEV & $\mathrm{AC}$ & EPS \\
\hline Beech & 26 & 168 & 0.098 & 0.140 & 0.507 & 0.933 \\
\hline Sugar Maple & 28 & 161 & 0.110 & 0.166 & 0.598 & 0.950 \\
\hline Yellow Birch & 15 & 156 & 0.148 & 0.201 & 0.378 & 0.880 \\
\hline Red Oak & 12 & 91 & 0.152 & 0.167 & 0.362 & 0.929 \\
\hline \multicolumn{7}{|l|}{ North Bay } \\
\hline Sugar Maple & 20 & 98 & 0.087 & 0.117 & 0.457 & 0.922 \\
\hline Yellow Birch & 6 & 171 & 0.219 & 0.264 & 0.308 & 0.595 \\
\hline Red Oak & 3 & 82 & 0.248 & 0.254 & 0.229 & 0.802 \\
\hline \multicolumn{7}{|l|}{ Algonquin } \\
\hline Sugar Maple & 36 & 149 & 0.088 & 0.103 & 0.350 & 0.968 \\
\hline By & 3 & 54 & 0.143 & 0.131 & 0.189 & 0.650 \\
\hline Or & 12 & 142 & 0.116 & 0.155 & 0.483 & 0.831 \\
\hline $\mathrm{Be}$ & 21 & 210 & 0.139 & 0.224 & 0.391 & 0.898 \\
\hline
\end{tabular}

MS = mean sensitivity, STDEV = standard deviation, AC = auto correlation, EPS = expressed population signal.

Yellow birch residual chronologies had similar positive responses in both Haliburton and North Bay study areas. PrJJAP and PrMJJAP showed significant effect on tree-ring width in both areas (Figure 7(c)). PrJulyP showed a strong negative relationship with the North Bay chronology while PrAugustP showed a strong positive relationship with the Haliubrton chronology. PrTotalP only displayed a positive response with the Haliburton chronology. The yellow birch residual chronology for Algonquin Park had no significant positive relationships with any of the climatic variables $(p<0.05)$. Many negative relationships were observed with these climate variables (PrTotalP, PrJJAP, PrMJJAP, GDD0, PrMayP, PrJulyP, MayP, JuneP, and PrMAT). The current year September precipitation (SeptP) was the only climate variable that significantly affected radial growth of yello birch negatively in Algonquin Park.

Red oak residual chronologies had the most negative responses with climatic variables out of all four species in this study. August precipitation from the current year (AugustP), SeptP, and PrMAT showed strong negative effects on red oak in Algonquin Park (Figure 7(d)). Other strong negative responses occurred with AugustP in the North Bay chronology and PrMAT in the Haliburton chronology. Positive responses were displayed in all three areas. PrJJAP, PrMJJAP, PrMayP, and PrJuneP were positively correlated with the red oak residual chronology in Haliburton. In Algonquin Park only PrMJJAP and PrMayP showed positive responses to red oak ring width residual chronologies (Figure 7(d)). PrJJAP, PrJulyP, and JulyP were the only climatic variables to show significant positive relationships with the residual chronology in North Bay.

Four composite chronologies were successfully developed, one for each target species over the entire study area, and analyzed against the same set of climate variables from a weather station located in a centralized area (Huntsville, ON). The red oak residual chronology had strong positive and negative responses to the climatic variables. PrMayP and PrJuneP showed strong positive responses, while PrAugustP and AugustP displayed significant negative effects on the residual ring width chronology for red oak (Figure 8). No significant correlations were found between tree-ring width and climate variables for yellow birch. The sugar maple and American beech residual chronologies showed similar strong positive responses to PrJJAP, PrMJJAP, PrJulyP, and JulyP. In addition the sugar maple residual chronology had a strong positive correlation with PrJuneP, while the American beech residual chronology had a significant negative correlation with PrTotalP.

\section{Discussion}

Mean sensitivity is an index that ranges from 0 to 2, no differences between successive ring widths to every second ring missing. Larger values indicate the presence of considerable high-frequency variance [8]. Nine of the eleven chronologies had mean sensitivities below 0.2, indicating the absence of high-frequency variation between ring widths. Only the yellow birch and red oak chronologies had values over 0.2 at 0.219 and 0.248 re- 
spectively in North Bay area (Table 3). The low mean sensitivity and standard deviation values indicate a low variability in ring width patterns. Since the variability is largely due to sensitivity of different species to climate fluctuations, our results would indicate that the species in the study region have a low sensitivity to climatic fluctuations as has been reported before [16]. Climate is believed to be less limiting to growth in northeastern North America than in southwestern North America [1] [36].

The expressed population signal (EPS) is an indicator of chronology reliability that is based on mean correlation between all series. The value ranges from 0.0 (no agreement) to 1.0 (perfect agreement), with a 0.85 value often being suggested as a threshold to determine the quality of tree-ring chronologies. This measure indicates how well the chronology compares to a theoretical chronology based on an infinite number of trees [8] [32]. Four of the eleven chronologies in this study failed to meet the 0.85 EPS threshold (Table 3). It has been noted that deciduous species have lower effective chronology signals and require higher sample sizes to meet the threshold, with up to 25 trees are required to reach an EPS of 0.85 [8]. The yellow birch (0.595) and red oak

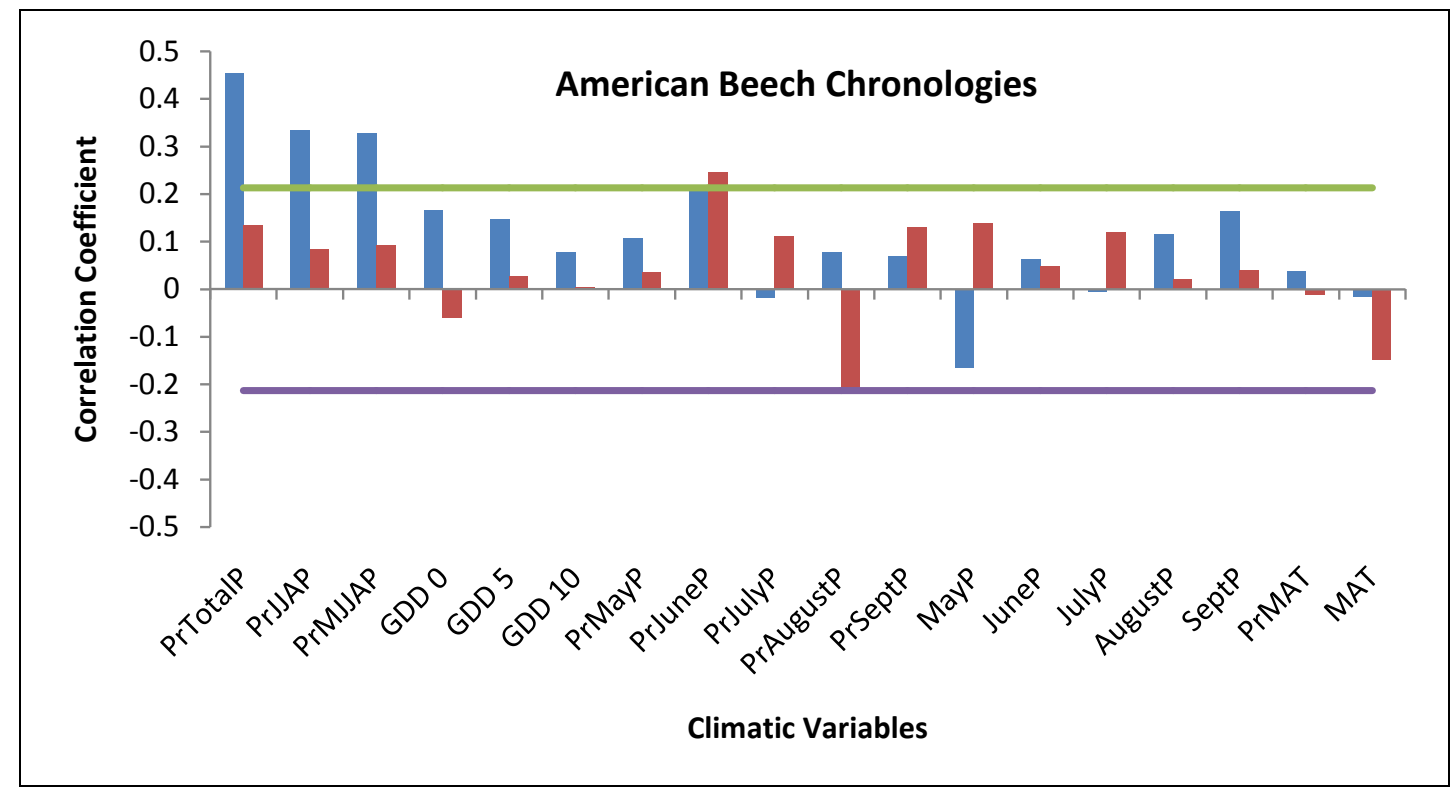

(a)

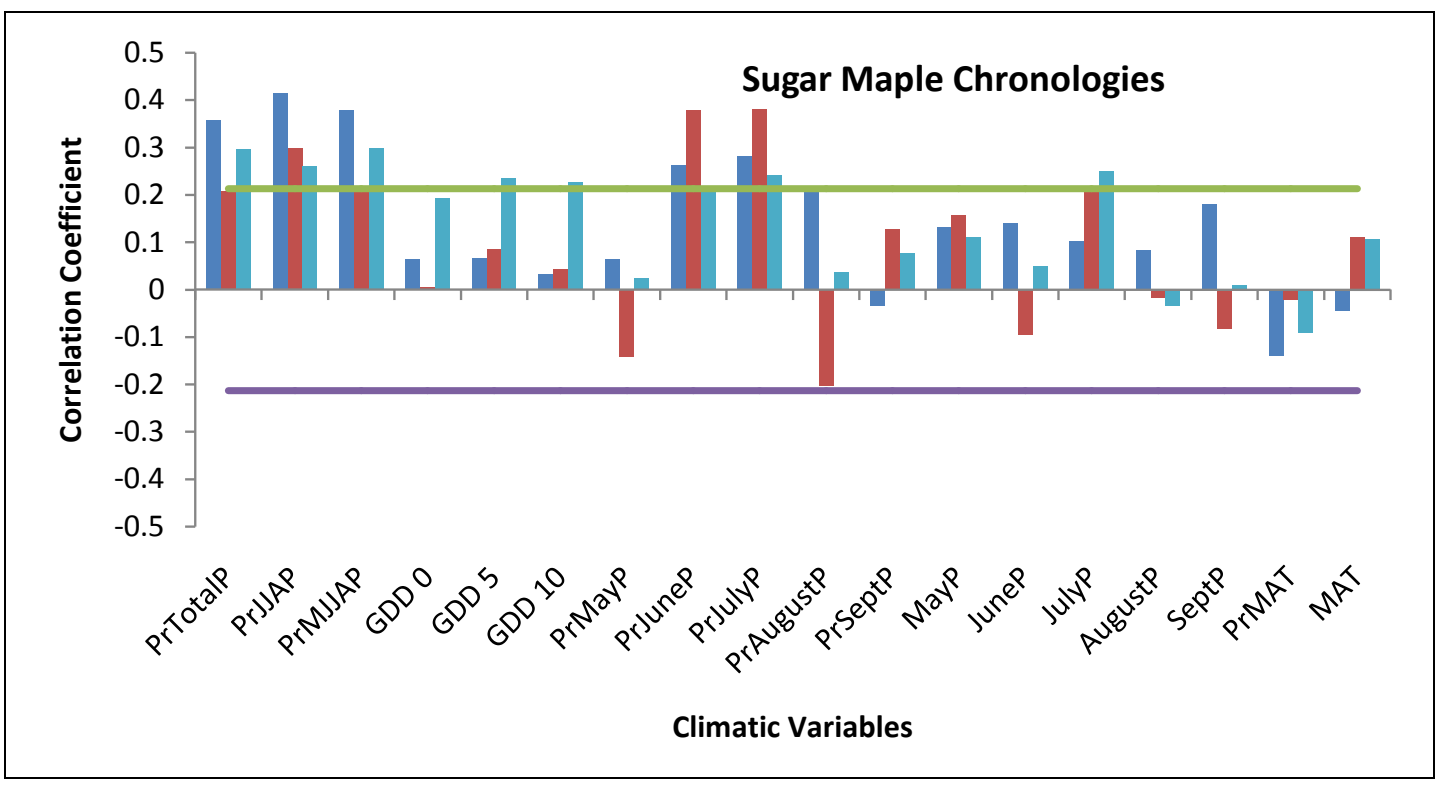

(b) 


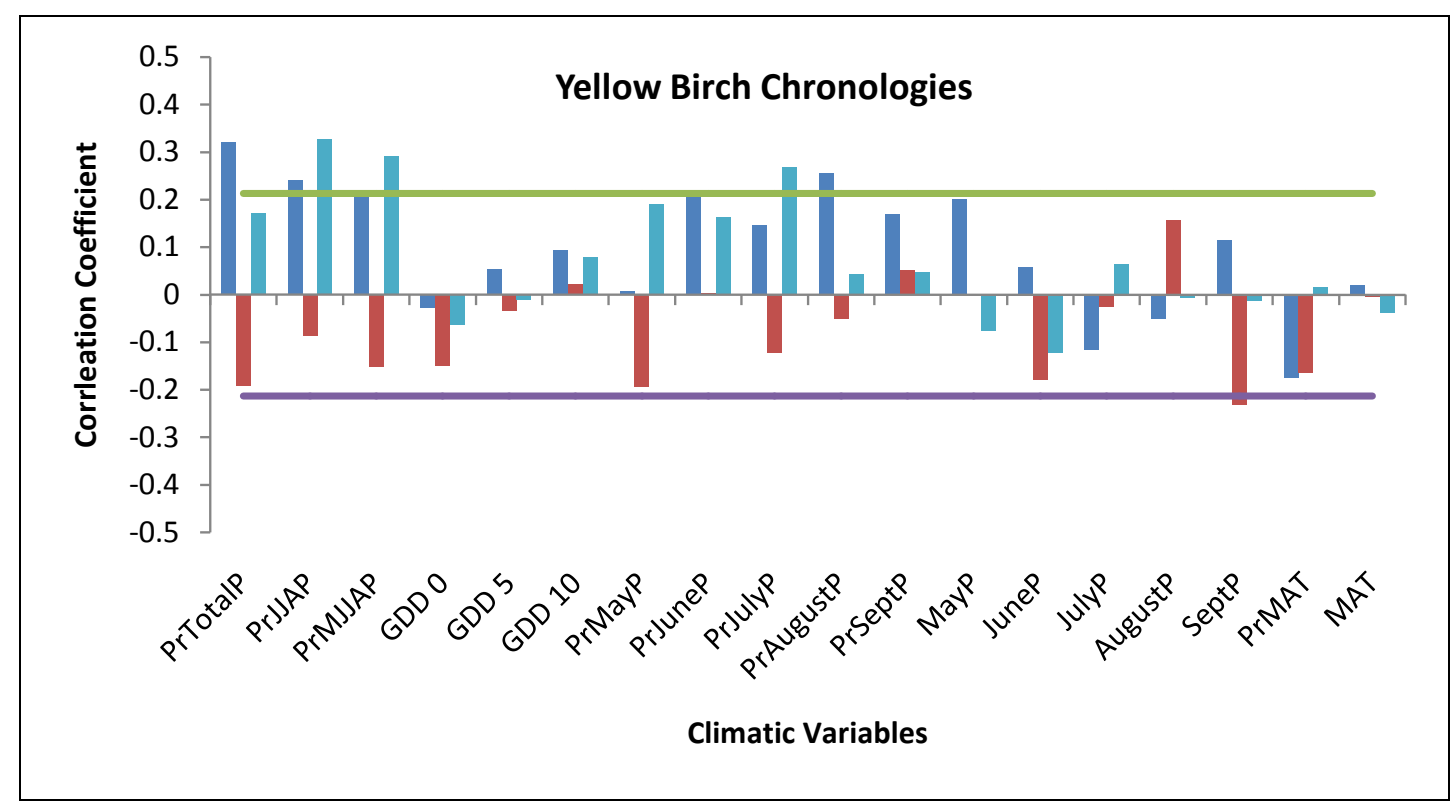

(c)

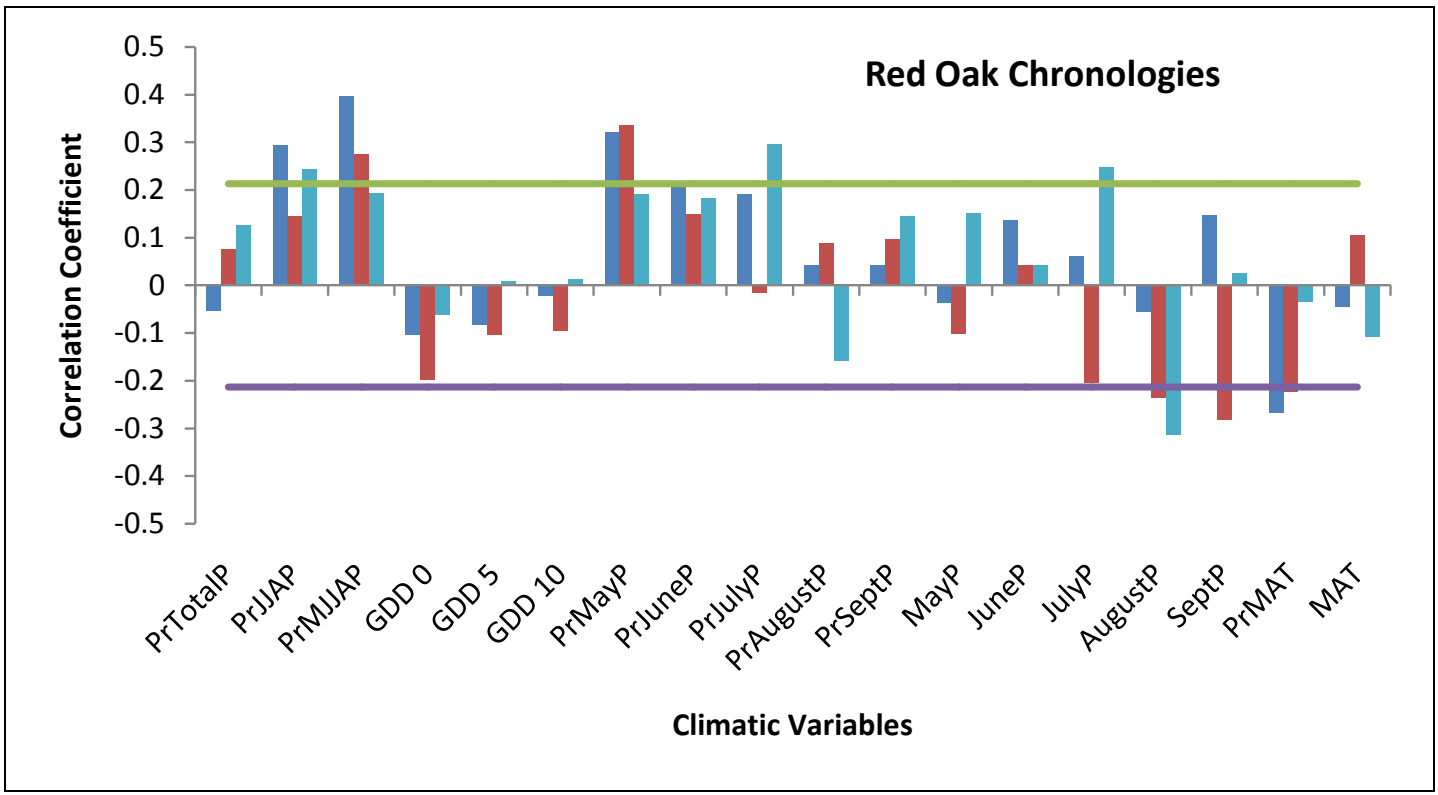

(d)

Figure 7. (a) Correlation coefficients between American beech ring width chronologies in Haliburton (blue), Algonquin Park (red) and climatic variables: the previous year total precipitation (PrTotalP), June thru August precipitation (PrJJAP), May thru August precipitation (PrMJJAP), growing degree days above 0, 5, and 10 degrees Celsius (GDD0, GDD5, GDD10), May previous year precipitation in May (PrMayP), June (PrJuneP), July (PrJulyP), August (PrAugustP), and September (PrSeptP), May precipitation (MayP), June precipitation (JuneP), July precipitation (JulyP), August precipitation (AugustP), September precipitation (SeptP), mean annual temperature for the previous year (PrMAT), and mean annual temperature (MAT). The solid lines indicate significant simple correlations at $p<0.05$ level $( \pm 0.213)$; (b) Correlation analysis between sugar maple ring width chronologies in Haliburton (blue), Algonquin Park (red), and North Bay (green), and climatic variables (Refer to Figure 7(a) for explanation of abbreviations). The solid lines indicate significant correlation value at the 0.05 level ( \pm 0.213$)$; (c) Correlation analysis between yellow birch ring width chronologies in Haliburton (blue), Algonquin Park (red), and North Bay (light grey), and climatic variables (Refer to Figure 7(a) for explanation of abbreviations). Dashed lines indicate significant correlation value at the 0.05 level $( \pm 0.213)$. (d) Correlation analysis between red oak ring width chronologies in Haliburton (blue), Algonquin Park (red), and North Bay (green), and climatic variables (refer to Figure 7(a) for explanation of abbreviations). The solid lines indicate significant correlation value at the 0.05 level $( \pm 0.213)$. 


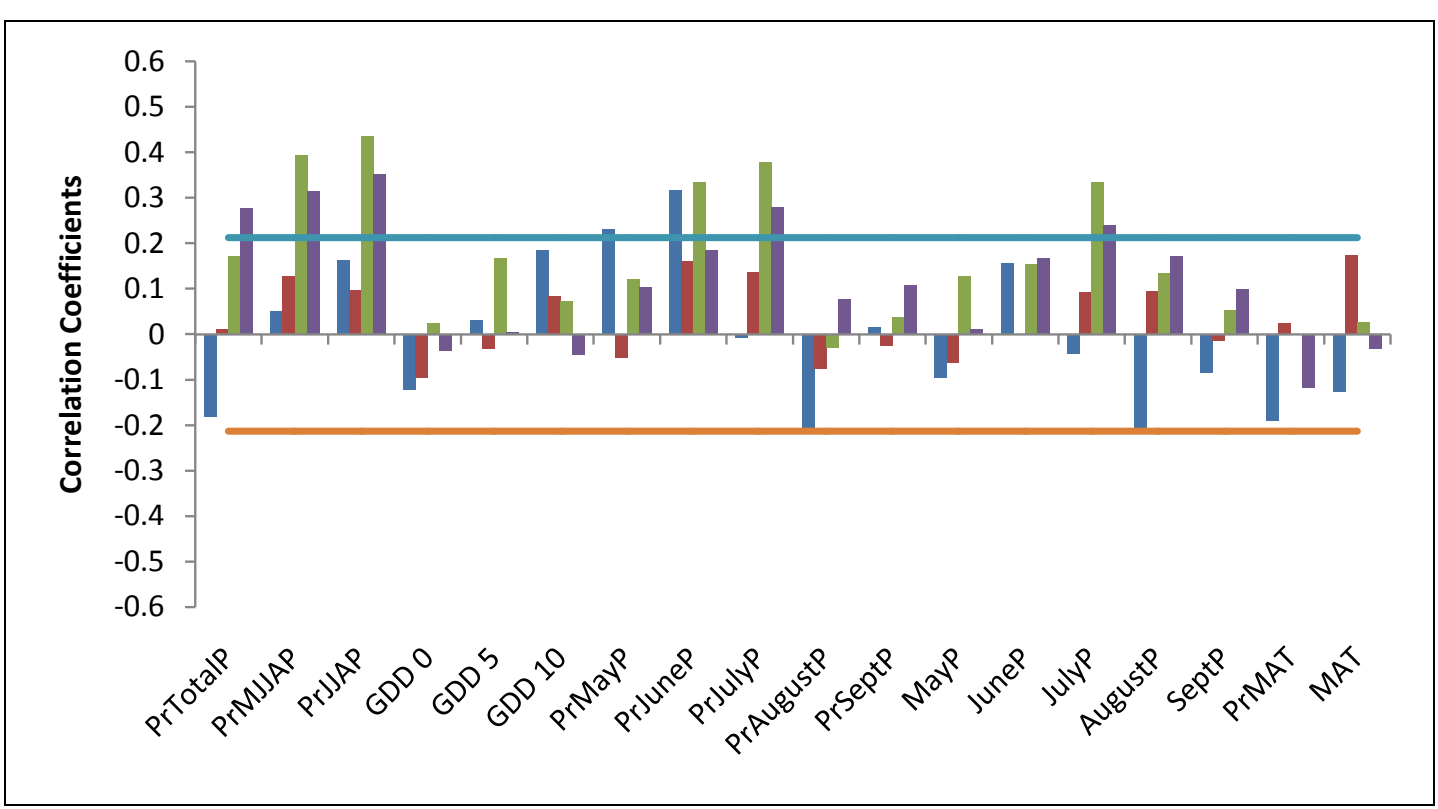

Figure 8. Correlation coefficients between species-specific regional chronologies of red oak (blue), yellow birch (red), sugar maple (yellow) and American beech (purple) in the entire study area (Huntsville, ON) and climatic variables: total precipitation for the previous year (PrTotalP), June thru August precipitation for the previous year (PrJJAP), May thru August precipitation for the previous year (PrMJJAP), growing degree days above 0, 5, and 10 degrees Celsius (GDD0, GDD5, GDD10), May precipitation for the previous year (PrMayP), June's precipitation for the previous year (PrJuneP), July precipitation for the previous year (PrJulyP), August's precipitation for the previous year (PrAugustP), September precipitation for the previous year (PrSeptP), May precipitation (MayP), June precipitation (JuneP), July precipitation (JulyP), August precipitation (AugustP), September precipitation (SeptP), mean annual temperature for the previous year (PrMAT), and mean annual temperature (MAT). The solid lines indicate significant correlation value at the 0.05 level $( \pm 0.213)$.

(0.802) chronologies of North Bay contained only 6 and 3 sample trees respectively. The yellow birch (0.650) chronology in Algonquin Park only contained 3 samples, while the red oak chronology was close to the threshold at 0.831 with only 12 samples. More samples from these areas are required to construct reliable chronologies that can be effectively linked to climatic variables in climatic reconstruction using ring widths.

Ring-width of American beech had significant correlations with total and growing season precipitation from the previous year in Haliburton. Our results of linking favourable climate conditions to radial growth coincide with bud formation during the prior year having a strong influence on the amount of foliage, and wood that is produced the following year [37]. Not only do drought years have a strong negative effect on American beech growth during the following season as found by [16] in southwestern Quebec, but if drought occurs throughout the current growing season it can cause radial growth to cease one month prematurely [21]. Our results supported these findings as significant positive correlations for American beech chronologies in both Haliburton and Algonquin Park with the June precipitation from the previous year (Figure 7(a)), and the strong positive response to July precipitation from the current and previous year found in all American beech samples (Figure 8). The growth cessation experienced during drought impedes radial growth during the current growing season and may limit allocation to bud formation and as a consequence may lead to smaller radial growth in the following year [37].

Our results for sugar maple were supported by other studies [11] [14]-[16] that significant positive correlations between radial growth and climatic variables exist. However, a study by [38] reported contrary results without any significant correlations. At all three sites and within the entire region chronologies of sugar maple showed that sufficient precipitation from the previous year's growing season had a positive impact on radial growth. July precipitation from the previous growing season showed identical results (Figure 7(b); Figure 8). Reduced water stress throughout the growing season, particularly the late summer allows for supplementary carbohydrate reserves [15]. Our results show a strong positive correlation with July precipitation during the current year, which is consistent with findings by [39] and [40] in Indiana, and [14] in southern Quebec. One study also showed that radial growth in sugar maples in Indiana had the highest correlation with July precipitation due 
to the warmer and drier environment [40]. Studies by [14] and [16] in Quebec showed negative correlations with May precipitation suggesting abundant precipitation during the spring could decrease growth due to excessive soil water content [16]. These findings further put the emphasis on the importance of microsite position for sugar maple on well drained soils to maximize growth potential. Positive correlations with growing degree days above $0^{\circ} \mathrm{C}$ and $5^{\circ} \mathrm{C}$ in North Bay (Figure 7(b)) signify the importance of warmer temperatures and longer growing seasons in sugar maple at the northern limit of its range in central Ontario.

Yellow birch in North Bay had positive correlations with precipitation during the previous growing season and more specifically in July, and in Algonquin Park a significant negative correlation with September precipitation in the current year was observed. However, due to the low expressed population signal (EPS) values for both chronologies resulting from low sample sizes (Table 3) it is difficult to conclude what factors may or may not effect radial growth in this region. In Haliburton, similar results were found as in North Bay regarding a strong positive correlation with precipitation from the previous growing season. Only August precipitation from the previous year (near the end of the growing season) showed a positive correlation. This coincides with He who found a strong positive correlation with November precipitation from the previous year (near the end of the growing season) in yellow birch studied in the Harvard Forest, Petersham, Massachusetts [17]. These findings would suggest that mature trees with deep root systems, such as yellow birch may use deeper water reserves [17]. Yellow birch found in the Harvard Forest is near the southern limit of its range in comparison to our study area and possesses a longer growing season [20]. Contrary to [17], our study did not find any correlations with specific months during the current growing season, would strengthen the suggestion that soil moisture is more important than precipitation in radial growth of yellow birch due to microsite position and poor soil drainage.

\section{Conclusion}

It is difficult to make reliable conclusions with the strong positive and negative correlations found regarding red oak chronologies in North Bay and Algonquin Park, as both EPS values are less than the 0.85 threshold (Table 3) mainly due to low sample sizes. Strong positive and negative responses have been found in our study for the Haliburton and overall (Huntsville) red oak chronologies. Radial growth in red oak was strongly related to growing season precipitation from the previous year in Haliburton, and May and June precipitation from the previous year in Haliburton and over the entire region. These results are similar to Tardif and Conciatori (2006) who found a positive association with June-August precipitation in the year prior to ring formation [9]. However, our results for August precipitation contradict those of Tardif and Conciatori [9] as the chronology of red oak over the entire region displayed a strong negative correlation during the current growing season, and the year prior to ring formation. It has been found that warm May conditions causing an earlier start to the growing season could increase the probability of water stress during the growing season and cause cambial activity to end prematurely [9]. It has been suggested that water stress in the early growing season is the most important factor influencing radial growth [41]-[45]. In general red oak in this region occurs on mesic to xeric sites (OMNR 1998). Tardif and Conciatori found that the absence of water stress during the year of ring formation leads to a thicker latewood zone resulting in a wider ring [9]. In Haliburton, red oak radial growth was negatively correlated to the mean annual temperature in the year prior to ring formation. This result could be further indicative of warm temperatures increasing the probability of water stress during the growing season, which would result in carbohydrate shortages required for bud formation in the coming year to sustain optimal radial growth. Our results provide insight into tree-ring responses of the four major broadleaf tree species in Ontario, Canada to climatic variables. The information can be used in prediction of impacts of climate change on the hardwood forest ecosystems in Ontario.

\section{Acknowledgements}

We thank Haliburton Forest and Wildlife Reserve, Ontario Ministry of Natural Resources and Algonquin Park for supporting our research as well Nick Buda and Alireza Rahi for field data collection. This study was supported with funding from the Ontario Living Legacy Trust and the Natural Sciences and Engineering Research Council of Canada.

\section{References}

[1] Fritts, H.C. (1976) Tree Rings and Climate. Academic Press, London, 567 p. 
[2] Bradley, R.S. and Jones, P.D. (1992) Climate since A.D. 1500. Routledge, London.

[3] Kienast, F., Wildi, O. and Brzeziecki, B. (1998) Potential Impacts of Climate Change on Species Richness in Mountain Forests-An Ecological Risk Assessment. Biological Conservation, 83, 291-305. http://dx.doi.org/10.1016/S0006-3207(97)00085-2

[4] Saxe, H., Cannell, M.G.R., Johnsen, O., Ryan, M.G. and Vourlitis, G. (2001) Tree and Forest Functioning in Response to Global Warming. New Phytologist, 149, 369-399. http://dx.doi.org/10.1046/j.1469-8137.2001.00057.x

[5] Sitch, S., Smith, B., Prentice, I.C., Arneth, A., Bondeau, A., Cramer, W., Kaplan, J.O., Levis, S., Lucht, W., Sykes, M.T., Thonicke, K. and Venevsky, S. (2003) Evaluation of Ecosystem Dynamic, Plant Geography and Terrestrial Carbon Cycling in the LPJ Dynamic Global Vegetation Model. Global Change Biology, 9, 161-185. http://dx.doi.org/10.1046/j.1365-2486.2003.00569.x

[6] Thuiller, W., Lavorel, S., Arujo, M.B., Sykes, M.T. and Prentice, I.C. (2005) Climate Change Threats to Plant Diversity in Europe. Proceedings of the National Academy of Sciences of the United States of America, 102, 8245-8250. http://dx.doi.org/10.1073/pnas.0409902102

[7] IPCC (2007) Climate Change 2007: The Physical Science Basis. Contribution of Working Group I to the Fourth Assessment Report on the Intergovernmental Panel on Climate Change. In: Solomon, S., Qin, D., Manning, M., Chen, Z., Marquis, M., Averyt, K.B., Tignor, M. and Miller, H.L., Eds., Cambridge University Press, Cambridge.

[8] Cook, E.R. and Kairiukstis, L.A. (1990) Methods of Dendrochronology. Applications in the Environmental Sciences. International Institute for Applied Systems Analysis. Kluwer Academic Publishers, Dordrecht, 394 p. http://dx.doi.org/10.1007/978-94-015-7879-0

[9] Tardif, J.C. and Conciatori, F. (2006) Influence of Climate on Tree Rings and Vessel Features in Red Oak and White Oak Growing near Their Northern Distribution Limit, Southwestern Quebec, Canada. Canadian Journal of Forest Research, 36, 2317-2330. http://dx.doi.org/10.1139/x06-133

[10] Yeh, H.Y. and Wensel, L.C. (2000) The Relationship between Tree Diameter Growth and Climate for Coniferous Species in Northern California. Canadian Journal of Forest Research, 30, 1463-1471. http://dx.doi.org/10.1139/x00-074

[11] Yin, X., Foster, N.W., Morrison, I.K. and Arp, P.A. (1994) Tree-Ring-Based Growth Analysis for a Sugar Maple Stand: Relations to Local Climate and Transient Soil Properties. Canadian Journal of Forest Research, 24, 1567-1574. http://dx.doi.org/10.1139/x94-204

[12] Dixon, R.K., Meldahl, R.S., Ruark, G.A. and Warren, W.G. (1990) Process Modeling of Forest Growth Responses to Environmental Stress. Timber Press, Portland.

[13] OMNR (2008) Annual Report on Forest Management for the Year 2005-2006. Queen’s Printer for Ontario, Ontario.

[14] Payette, S., Fortin, M.J. and Morneau, C. (1996) The Recent Sugar Maple Decline in Southern Quebec: Probable Causes from Tree Rings. Canadian Journal of Forest Research, 26, 1069-1078. http://dx.doi.org/10.1139/x26-118

[15] Lane, C.J., Reed, D.D., Mroz, G.D. and Liechty, H.O. (1993) Width of Sugar Maple (Acer saccharum) Tree Ring as Affected by Climate. Canadian Journal of Forest Research, 23, 2370-2375. http://dx.doi.org/10.1139/x93-292

[16] Tardif, J.C., Brisson, J. and Bergeron, Y. (2001) Dendroclimatic Analysis of Acer saccharum, Fagus grandifolia, and Tsuga canadensis from an Old-Growth Forest, Southwestern Quebec. Canadian Journal of Forest Research, 31, 14911501. http://dx.doi.org/10.1139/cjfr-31-9-1491

[17] He, J.S., Zhang, Q.B. and Bazzaz, F.A. (2005) Differential Drought Responses between Saplings and Adult Trees in Four Co-Occurring Species of New England. Trees, 19, 442-450. http://dx.doi.org/10.1007/s00468-004-0403-2

[18] Godman, R.M., Yawney, H.W. and Tubbs, C.H. (1990) Sugar Maple. In: Burns, R.M. and Honkala, B.H., Eds., Silvics of North America: 2. Hardwoods, Agriculture Handbook 654, USDA Forest Service, Washington DC.

[19] Siccama, T.G. (1974) Vegetation, Soil and Climate on the Green Mountains of Vermont. Ecological Monographs, 44, 325-349. http://dx.doi.org/10.2307/2937033

[20] Erdmann, G.G. (1990) Yellow Birch. In: Burns, R.M. and Honkala, B.H., Eds., Silvics of North America: 2. Hardwoods, Agriculture Handbook 654, USDA Forest Service, Washington DC.

[21] Tubbs, C.H. and Houston, D.R. (1990) American Beech. In: Burns, R.M. and Honkala, B.H., Eds., Silvics of North America: 2. Hardwoods, Agriculture Handbook 654, USDA Forest Service, Washington DC.

[22] USDA (1965) Silvics of Forest Trees of the United States. Fowells, H.A., Comp. Agriculture Handbook 271, US Department of Agriculture, Forest Service, Washington DC, 762 p.

[23] USDA (1975) Soil Taxonomy: A Basic System of Soil Classification for Making and Interpreting Soil Surveys. Soil Survey Staff, Coord., Soil Conservation Service. Agriculture Handbook 436, US Department of Agriculture, Washington DC, $754 \mathrm{p}$.

[24] Sander, I.L. (1990) Northern Red Oak. In: Burns, R.M. and Honkala, B.H., Eds., Silvics of North America: 2. Hard- 
woods, Agriculture Handbook 654, USDA Forest Service, Washington DC.

[25] Zasada, J.C. and Zahner, R. (1969) Vessel Element Development in the Earlywood of Red Oak (Quercus rubra). Canadian Journal of Botany, 47, 1965-1971. http://dx.doi.org/10.1139/b69-288

[26] Aloni, R. (1991) Wood Formation in Deciduous Hardwood Trees. In: Raghavendra, A.S., Ed., Physiology of Trees, John Wiley and Sons, New York, 75-197.

[27] Burns, R.M. and Honkala, B.H. (1990) Silvics of North America: 2. Hardwoods. Agriculture Handbook 654, USDA Forest Service, Washington DC.

[28] Buda, N.J. and Wang, J.R. (2006) Suitability of Two Methods of Evaluating Site Quality for Sugar Maple in Central Ontario. The Forestry Chronicle, 82, 733-744. http://dx.doi.org/10.5558/tfc82733-5

[29] Regent Inc. (2001) WinDendro Tree Ring Increment Measurement Software and XL Stem 1.3 Macro.

[30] Cook, E.R. (1985) A Time Series Analysis Approach to Tree Ring Standardization. Dissertation, University of Arizona, Tucson.

[31] Cook, E.R. and Peters, K. (1981) The Smoothing Spline: A New Approach to Standardizing Forest Interior Tree-Ring Width Series for Dendroclimatic Studies. Tree-Ring Bulletin, 41, 45-53.

[32] Wigley, T.M.L., Briffa, K.R. and Jones, P.D. (1984) On the Average Value of Correlated Time Series, with Applications in Dendroclimatology and Hydrometeorology. Journal of Climate and Applied Meteorology, 23, 201-213. http://dx.doi.org/10.1175/1520-0450(1984)023<0201:OTAVOC>2.0.CO;2

[33] Parr, J. and Phillips, C. (1999) Signals, Systems, and Transforms. Second Edition. Prentice Hall, Upper Saddle River.

[34] Environment Canada (2005) Canadian Climate Data. October 15, 2008. http://www.climate.weatheroffice.ec.gc.ca/climateData/canada_e.html

[35] Schweingruber, F.H. (1996) Tree Rings and Environment-Dendrochronology. Haupt, Bern, 609 p.

[36] Phipps, R.L. (1982) Comments on Interpretation of Climatic Information from Tree Rings, Eastern North America. Tree-Ring Bulletin, 42, 11-22.

[37] Kozlowski, T.T. and Pallardy, S.G. (1997) Physiology of Woody Plants. Academic Press, New York.

[38] Houle, G. (1990) Growth Patterns of Sugar Maple Seedlings and Mature Trees in Healthy and in Declining Hardwood Stands. Canadian Journal of Forest Research, 20, 894-901. http://dx.doi.org/10.1139/x90-120

[39] Friesner, G.M. and Friesner, R.C. (1942) Relation of Annual Ring Formation as Illustrated in Six Species of Trees in Marshall County, Indiana. Butler University Botanical Studies, 5, 96-112.

[40] Miller, C.W. (1951) Growth Data from Nine Sections of Acer saccharum from Montgomery County, Indiana. Butler University Botanical Studies, 107, 12-19.

[41] Fritts, H.C. (1962) The Relation of Growth Ring Widths in American Beech and White Oak to Variation in Climate. Tree-Ring Bulletin, 25, 2-10.

[42] Foster, J.R. and LeBlanc, D.C. (1993) A Physiological Approach to Dendroclimatic Modeling of Oak Radial Growth in the Midwestern United States. Canadian Journal of Forest Research, 23, 783-798. http://dx.doi.org/10.1139/x93-103

[43] LeBlanc, D. and Terrel, M. (2001) Dendroclimatic Analyses Using the Thornthwaite-Mather-Type Evapotranspiration Model: A Bridge between Dendroecology and Forest Simulation Models. Tree-Ring Research, 57, 55-66.

[44] Terrel, M. and LeBlanc, D. (2002) Spatial Variation in Response of Northern Red Oak to Climate Stresses in Eastern North America. In: Begin, Y., Ed., Dendrochronology, Environmental Change and Human History: Proceedings of the 6th International Conference on Dendrochronology, 22-27 August 2002, Quebec City, Les Presses de l’Universite Laval, Quebec City, 340-343.

[45] OMNR (1998) A Silvicultural Guide for the Tolerant Hardwood Forest in Ontario. Ontario Ministry of Natural Resources, Queen's Printer for Ontario, Toronto, 500 p. 